\title{
Előszó - „Barátság extrákkal”
}

\author{
Az életminőség alakulása Nyíregyházán az elmúlt tíz évben
}

2007. Ez volt az az év, amikor is Deme Dórával, Nyíregyháza Város (akkori nevén) Szociális Irodájának vezetőjével először ültünk le és találtuk ki a ma már életminöség kutatássá alakult vizsgálatsorozatot. Mindkettőnk számára az volt az igazán fontos, hogy ne egy pillanatfelvétel készüljön a város lakóiról, hanem hogy folyamatosan vizsgáljuk az életkörülmények alakulását.

A személyes megbeszélést egy intenzív előkészítő munka követte. Kialakult a kutatói stáb, akik egy-egy témakör gazdáivá váltak, megszületett a vizsgálathoz használt kérdőív. Módszertanilag panelvizsgálatot (ráadásul egy nagymintás panelvizsgálatot) terveztünk, hogy követni tudjuk a lakosság életében bekövetkezett változásokat. Persze ehhez voltak már minták, nemzetközi és hazai elözmények, amelyek nagyban segítették a tervező munkát.

Az első adatfelvételre 2008-ban került sor, ezt követték az újabb hullámok, 2010ben, 2012-ben, 2015-ben és 2018-ban. Söt, a kutatás bővült, hiszen 2015-ben nemcsak a városban, hanem Nyíregyháza járásban is elvégezhettük a vizsgálatot, majd röviddel ezután a városban élő fiatalok életkörülményeit is felmérhettük. 2018-ban sor került az egészségi állapot tematikus felmérésére is, 2019-töl pedig egy sikeres pályázatnak köszönhetően vizsgáljuk a telepszerü körülmények között élők életminőségét. Az első számú partner tulajdonképpen nem változott, bár elnevezése és feladatköre módosult, ma Nyíregyháza Megyei Jogú Város Szociális és Köznevelési Osztálya, vezetője pedig Dr. Krizsai Anita, aki nemcsak „megrendelő”, hanem témagazdaként tagja a kutatócsoportnak is.

Bár a kérdőiv az elmúlt tíz évben néhány helyen módosult és kiegészült, elsősorban az adatfelvételek eredményeire tekintettel, a föbb témakörök változatlanok. Mivel a kutatócsoport az életminőséget többdimenziós fogalomként kezeli, a kérdoív a következő blokkokat tartalmazza:

1. A háztartások jellemzöi (háztartás összetétele, lakhatás körülményei, problémák, háztartások felszereltsége, jövedelmek,)

2. Gazdasági aktivitás (munkavégzéssel kapcsolatos jellemzők)

3. Egészségi állapot (egészségi állapot megítélése, tartós betegségek)

4. Társas kapcsolatok (családi és emberi kapcsolatok jellemzöi, kiterjedtsége, intenzitása)

5. Idősek helyzete (a 65 éves, illetve annál idősebb lakosok helyzete)

6. Támogató rendszerek szociális problémák (a természetes és mesterséges védőháló jellemzői, segélyezés, vélemények a segélyezési rendszerekről, szociális ellátásról)

7. Szociális Iroda múködése (ügyfelek és véleményük)

8. Biográfia (a megkérdezettek személyes jellemzői) 
Hogyan írható le az elmúlt tíz év? Alapvetően két, markánsan elkülönülő időszakról beszélhetünk. Míg 2008 és 2012 között, alapvetően a nemzetközi gazdaságifinanciális krízis hatására, az életminőség szinte összes mutatója romlott (vagy stagnált) a városban, addig 2012-2013 óta jelentős javulás tapasztalható. 2018-ra jelentősen nőtt a foglalkoztatottság, nőttek a jövedelmek, csökkent a szegénységben élők aránya, ennek értelmében csökkent azok száma és aránya is, akik valamilyen szociális támogatásban részesülnek. A nyíregyháziak többsége ma már jónak, vagy kifejezetten jónak tartja egészségi állapotát, a kezdő évhez viszonyítva egyre többen számolnak be intenzív társasági életről, és egyre gyarapszik a barátok száma is. A nyíregyháziak köszönik szépen, jól vannak.

Ugyanakkor az adatok arra is egyértelmúen rávilágítanak, hogy bár az életminőség javulása (amit ma már egy önállóan kidolgozott, lokális életminőség index-el is mérni tudunk) a helyi társadalom egy jelentő részére jellemzővé vált, kirajzolódik egy olyan csoport képe is, akik többszörös hátrányokkal küzdenek, szegénységben és részben szegregációban élnek, rossz lakhatási körülmények között, foglalkoztatottságuk és társadalmi integrációjuk elégtelen.

A kutatás adatai két másik tendenciára is felhívják a figyelmet. Egyrészt a város mindig is sziget volt a szárazföldön, hiszen bármelyik mutatót vizsgáljuk is, Nyíregyháza kedvezőbb helyzetben volt és van, mint a környező térségek, azaz a megye, illetve az Észak-Alföld régió. Ez még a gazdasági válság időszakában is jellemző volt. Másrészt a város számos mutató tekintetében tulajdonképpen „leköveti” az országos változásokat, akár negatív, vagy pozitív változásról van szó, ez a csúszás pedig általában egy, másfél évet jelent.

Hogyan tovább? A kutatássorozatot természetesen folytatni kívánjuk, hiszen mai társadalmunkat a rapid változások jellemzik, amelyek természetesen a nyíregyháziak életét is meghatározzák. Nem látunk ugyan a jövőbe, de ennek ellenére úgy véljük, hogy az nem egy tölünk teljesen független dolog, részben olyan lesz, amilyenné tesszük. Nyíregyházán is. Munkával, társasággal, a barátainkkal.

\section{Fábián Gergely}

tanszékvezető, főiskolai tanár 